\title{
RESPONS ESTRUS SAPI RESIPIEN FH YANG DISINKRONISASI DENGAN HORMONE GnRH, ESROGEN, PROGESTERON DAN PROSTAGLANDIN
}

\section{ESTRUS RESPONSE OF FH COWS RECIPIENT AFTER SYNCHRONIZED WITH GnRH HORMONE, ESROGEN, PROGESTERON DAN PROSTAGLANDIN}

\author{
R Handarini1a, S Kurniawan², dan E Dihansih'1 \\ ${ }^{1}$ Program Studi Peternakan, Fakultas Pertanian, Universitas Djuanda Bogor Jl. Tol Ciawi No. 1, Kotak Pos \\ 35 Ciawi, Bogor 16720. \\ ${ }^{2}$ Balai Embrio Ternak Cipelang Bogor, Kp. Pasir Pogor, Desa Cipelang, Kecamatan Cijeruk, Kabupaten \\ Bogor, 16004. \\ a Korespondensi: Ristika Handarini, E-mail: ristika.handarini@unida.ac.id \\ (Diterima: 10-01-2016; Ditelaah: 10-01-2016; Disetujui: 16-02-2017)
}

\begin{abstract}
This study was aimed to test the effectiveness injection of several combination hormone of GnRh, estrogen, progesterone and prostaglandin e to the response of estrus, onset estrus and duration of estrus Friesian Holstein dairy cows recipient. This study was used fifteen dairy cows recipient not pregnant, which were divided into three treatment method of synchronization of estrus. The three treatments were P1: injection 137,5/5 ml prostaglandin hormone (Capriglandin) on day0 and repeat on day-11, P2: injection GnRh (Fertagyl) $100 \mu \mathrm{g} / 2 \mathrm{ml}$ on day-4 and injection prostaglandin hormone (Prostavet) $2 \mathrm{ml}$ on day-11, and P3: injection progesterone hormone (Potahormon) $250 \mathrm{~g} / 40 \mathrm{ml}$ and estrogen hormone (Ovalumon) 40,000 IU/ $2 \mathrm{ml}$ on day-5 and injection prostaglandin hormone (Capriglandin) $137,5 \mathrm{mg} / 5 \mathrm{ml}$ on day-11. Data was analyzed by Chi-Square Analysis for all of the parameters, IE: estrus response, onset estrus and duration of estrus, The results showed that presentage of response estrus $\mathrm{FH}$ cows recipient after injection of a hormone estrus combination overall reaches $100 \%$, onset estrus 72 hours (60\%) and duration of estrus 72 hours. The treatments were effective way for synchronization of estrus FH cows recipient. It was concluded that synchronization of estrus FH cows recipient using GnRH hormone, estrogen, progesterone and prostaglandin as good in all of the parameters. Recommendation for synchronization of estrus using injection progesterone hormone (Potahormon) $250 \mathrm{~g} / 40 \mathrm{ml}$ and estrogen hormone (Ovalumon) 40,000 IU/ $2 \mathrm{ml}$ on day-5 and injection prostaglandin hormone (Capriglandin) $137,5 \mathrm{mg} / 5 \mathrm{ml}$ on day-11.
\end{abstract}

Keywords: estrus response, estrogen and progesterone, $\mathrm{FH}$ cows, GnRh hormone, prostaglandin.

\section{ABSTRAK}

Penelitian ini bertujuan untuk menguji efektivitas penyuntikan kombinasi hormone GnRH, estrogen, progesteron dan prostaglandin terhadap respon estrus, onset estrus dan durasi estrus sapi FH resipien. Penelitian ini menggunakan 15 ekor sapi FH resipien tidak bunting, yang akan mendapat perlakuan. Perlakuan dalam penelitian ini adalah: P1 = Penyuntikan hormon prostaglandin (Capriglandin) 137,5 mg/ $5 \mathrm{ml}$ pada hari ke-0 dan hari ke 11 dengan dosis yang sama, P2 = Penyuntikan hormon GnRH (Fertagyl) $100 \mu \mathrm{g} / 2 \mathrm{ml}$ pada hari ke-4 dan penyuntikan hormon protaglandin (Prostavet) $2 \mathrm{ml}$ pada hari ke-11, dan P3 = Penyuntikan hormon progesterone (Potahormon) $250 \mathrm{~g} / 40 \mathrm{ml}$ dan estrogen (Ovalumon) 40,000 IU/ $2 \mathrm{ml}$ pada hari ke-5 dan penyuntikan hormon prostaglandin (Capriglandin) 137,5 mg/ $5 \mathrm{ml}$ pada hari ke-11. Data dianalisis menggunakan Chi-Square untuk semua paramers. Hasil penelitian menunjukkan bahwa respon estrus sapi yang diberi perlakuan menunjukkan gejala estrus (100\%), onset estrus pada hari ketiga (72 jam setelah disinkronisasi) dan lama estrus selama 3 hari (72 jam). 
Semua perlakuan merupakan cara yang efektif untuk sinkronisasi estrus. Kesimpulan penelitian adalah sinkronisasi estrus resipient sapi FH dengan menggunakan hormone GnRH, estrogen, progesteron dan prostaglandin memberikan hasil sama baiknya pada semua parameter. Disarankan untuk aplikasi dilapangan menggunakan hormon progesteron (Potahormon) $250 \mathrm{~g} /$ $40 \mathrm{ml}$ pada hari ke-0, hormon estrogen (Ovalumon) 40,000 IU/ $2 \mathrm{ml}$ hari ke-5 dan injeksi hormon prostaglandine (Capriglandin) 137,5 mg/ $5 \mathrm{ml}$ pada kari ke-11.

Kata kunci: estrogen dan progesteron, GnRh, prostaglandin, respons estrus, sapi FH.

Handarini R, S Kurniawan, dan E Dihansih. 2017. Respons estrus sapi resipien FH yang disinkronisasi dengan hormon $\mathrm{GnRH}$, esrogen, progesteron dan prostaglandin. Jurnal Pertanian 8(1): 16-25.

\section{PENDAHULUAN}

Mengantisipasi perkembangan kebutuhan protein hewani masyarakat terhadap kebutuhan susu dan daging perlu dikembangkan ternak ruminansia besar khususnya sapi perah dan sapi potong. Konsumsi susu per kapita per tahun masyarakat Indonesia hanya sekitar 7 liter per tahun, sedangkan konsumsi daging per kapita per tahun masyarakat Indonesia hanya sekitar 7,75 kg per tahun (Direktorat Jenderal Peternakan 2009). Impor daging sapi terhitung tanggal 31 Maret 2014 realisasinya baru mencapai $17.374,64$ ton atau hanya 34,04 persen dari SPI yang dikeluarkan periode Januari - Maret yaitu sebanyak $51.037,47$ ton kepada 75 perusahaan (Direktorat Jenderal Peternakan 2014).

Guna memenuhi kebutuhan protein hewani penerapan teknologi reproduksi merupakan salah satu upaya untuk meningkatkan populasi ternak. Peningkatkan efisiensi reproduksi dalam usaha peternakan melalui sinkronisasi estrus, merupakan salah satu cara yang dapat ditempuh untuk mendukung efisiensi manajemen reproduksi ternak. Sinkronisasi estrus merupakan proses reproduksi yang berkaitan dengan mekanisme sistem hormonal, yaitu hubungan antara hormon-hormon hipotalamus hipofisa yakni gonadotrophin releasinghormone (GnRH), follicle stimulating hormone (FSH) dan luteinizing hormone (LH), hormonhormon ovarium estrogen, progesteron dan hormon uterus prostaglandin (Hafez 2000). Sinkronisasi estrus dapat dilakukan dengan pemberian hormon GNRH, estrogen, progesterone dan PGF2 $\alpha$ atau pemberian kombinasi ke empatnya.

Gonadothropin Releasing Hormon (GnRH) akan menstimulasikan sel-sel gonadotroph kelenjar pituitari untuk mensekresikan Follicle Stimullating Hormon (FSH) dan Luteinizing Hormon (LH) yang bekerja pada target organ gonad (Colazo 2005; Sonjaya 2005), yaitu menstimulasikan sel-sel granulosa untuk memfasilitasi proses oogenesis dan ovulasi. Estrogen merupakan hormon steroid yang dihasilkan oleh sel granulosa dan sel teka dari folikel de Graaf pada ovarium yang berfungsi untuk merangsang estrus, munculnya sifat-sifat kelamin sekunder, mempertahankan sistem saluran dan pertumbuhan ambing (Wodzicka 1991; Hardjopranjoto 1995).

Progesteron merupakan hormon yang pertama kali digunakan dalam program sinkronisasi estrus pada sapi (Cerri 2004; Tenhagen 2004). yang berfungsi menekan aktivitas folikuler melalui pencegahan pelepasan gonadotropin dari hipofisis (Hafez 2000; Larson 2006). Penggunaan PGF $2 \alpha$ baik secara sendiri maupun dikombinasikan dengan hormon lain bertujuan untuk melisiskan corpus luteum (CL) sehingga terjadi perkembangan folikuler. Panjang siklus estrus normal pada sapi induk $21 \pm 3$ hari dan sapi dara $20 \pm 2$ hari, walaupun ada sedikit variasi bangsa sapi. Kebanyakan bangsa sapi mempunyai rata-rata lama estrus 12 jam dengan variasi normal antara 8 sampai 16 jam. Waktu ovulasi pada sapi umumnya terjadi sekitar 12 jam dari akhir estrus (Marawali 2001), 12 - 24 jam (Putro 2008; Putro dan Kusumawati 2014). 
Berbagai produk komersial dari hormonhormon diatas telah diproduksi dan terus dikembangkan, hanya saja harganya yang mahal dan belum ada yang diproduksi di Indonesia mengakibatkan agak sulit dalam pengadaannya. Kombinasi aplikasi dari hormon tersebut juga memberikan respon yang berbeda oleh karena itu penelitian dari aplikasi hormon sangat diperlukan untuk efisiensi program sinkronisasi estrus.

Penelitian ini bertujuan untuk menguji efektivitas penyuntikan kombinasi hormon GNRH, estrogen, progesteron dan PGF2 $\alpha$ terhadap respon estrus, lama estrus dan presentasi estrus sapi perah resipien Friesian Holstain. Hasil penelitian ini diharapkan

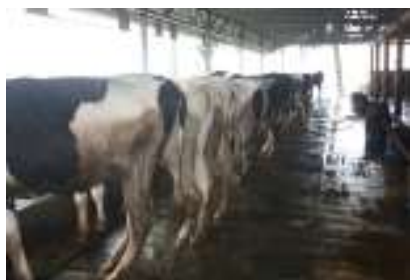

(a)

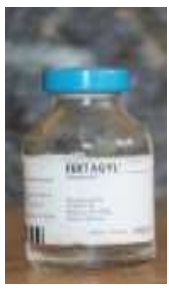

(b)

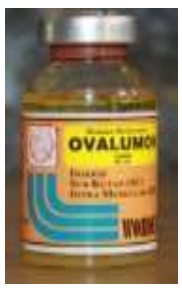

(c)

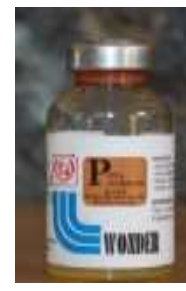

(d)

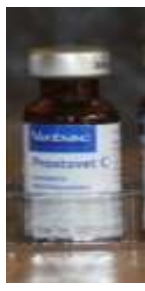

(e)

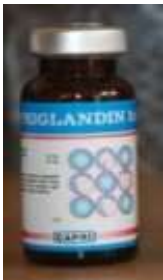

(f)

Gambar 1 Keterangan: (a) sapi resipien FH (Friesian Holstein), (b) hormon GnRH (Fertagyl 20 $\mathrm{ml}$ ), (c) hormon estrogen (Ovalumon $20 \mathrm{ml}$ ), (d) hormon progesteron (Potahormon $20 \mathrm{ml}$ ), (e) hormon prostaglandin (Prostavet $2 \mathrm{ml}$ ), (f) hormon prostaglandin (Capriglandin).

\section{Bahan dan Alat Penelitian}

Penelitian ini akan menggunakan 15 ekor sapi resipien bangsa FH (FriesianHolstein) dengan persyaratan: performa tubuh baik dan sehat, Body Condition Scor (BCS) 2,7 - 3,0, sapi dara atau induk dengan umur maksimal 3 - 5 tahun, memiliki catatan reproduksi yang baik dengan siklus estrus normal serta bebas dari penyakit reproduksi menular (Brucelosis, Leptospirosis, Vibriosis, Trichomoniasis dan IBR). Hormon yang digunakan: hormon GnRH (Fertagyl $20 \mathrm{ml}$ ), Estrogen (Ovalumon $20 \mathrm{ml}$ ), Progesteron (Potahormon $20 \mathrm{ml}$ ) dan Prostaglandin (Capriglandine $10 \mathrm{ml}$ dan Prostavet $2 \mathrm{ml}$ ), alkohol, kapas dan tissue (lihat Gambar 1). Peralatan yang digunakan adalah spuit berukuran $6 \mathrm{ml}$, jarum suntik berukuran 18 dan $22 \mathrm{G}$, dan sarung tangan.

\section{Rancangan dan Analisis Data}

Penelitian ini menggunakan 15 ekor sapi resipien yang diberi 3 perlakuan (setiap perlakuan terdiri atas 5 ekor sapi betina resipien). Perlakuan dalam penelitian ini adalah:

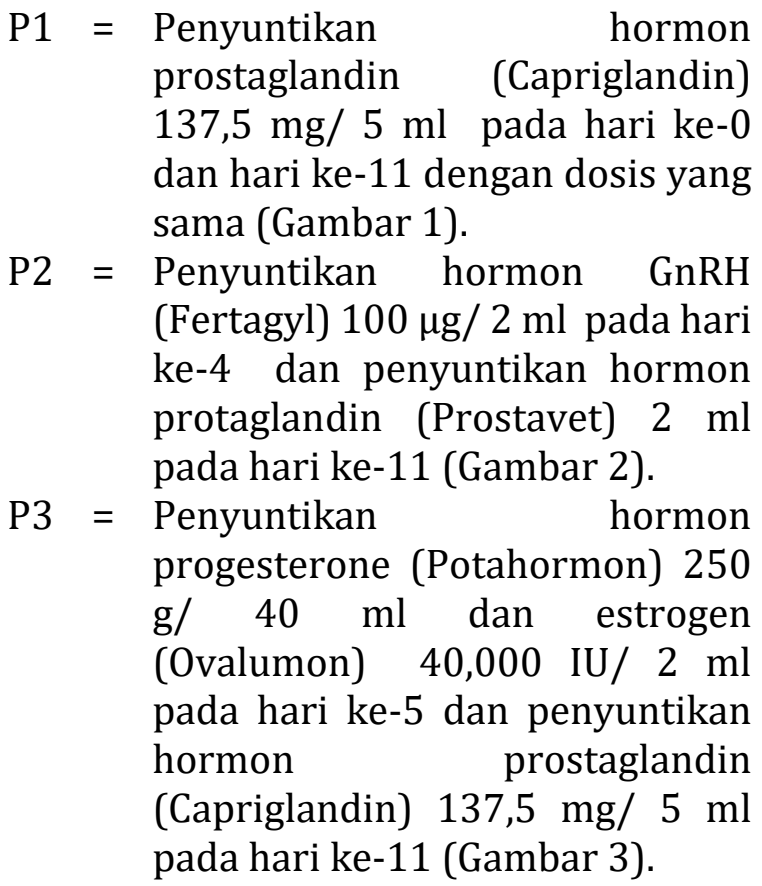

Data dianalisis dengan Chi-Kuadrat untuk membandingkan respons dari ketiga 
perlakuan sinkronisasi. Frekuensi hasil observasi (0) dan frekuensi yang diharapkan (E).

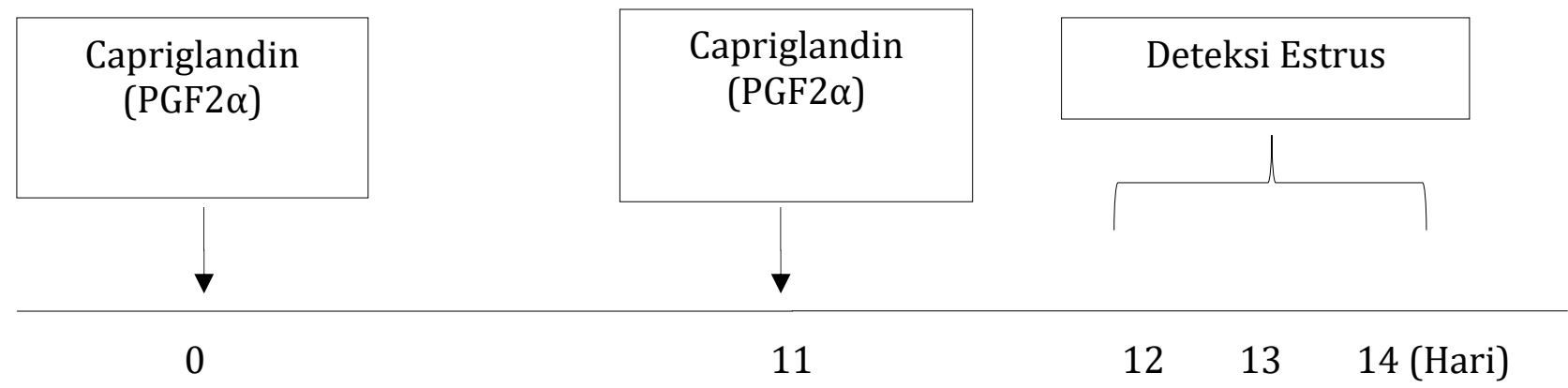

Gambar 2 Perlakuan 1

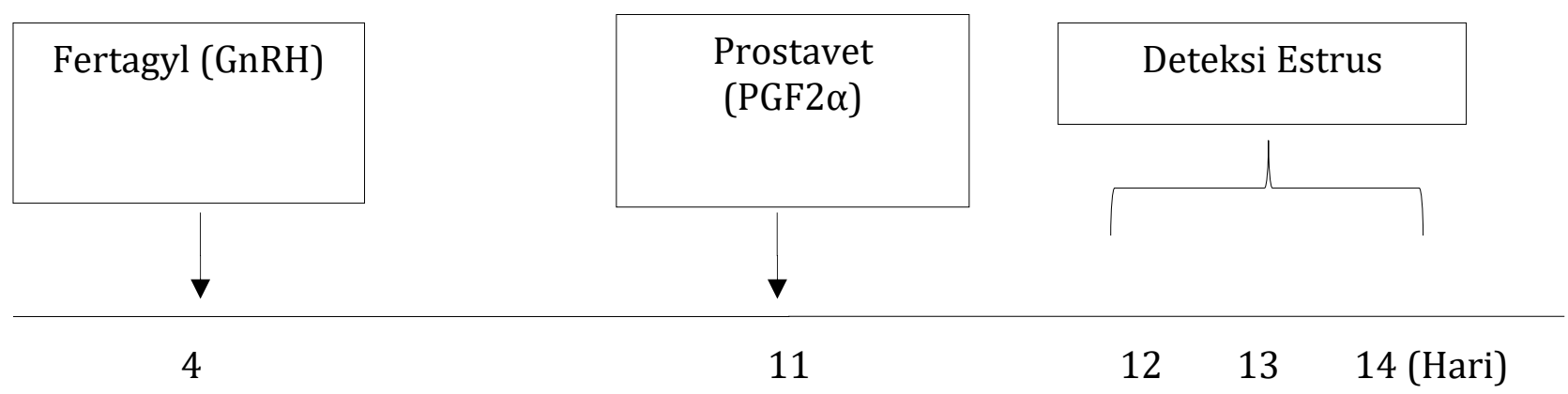

Gambar 3 Perlakuan 2

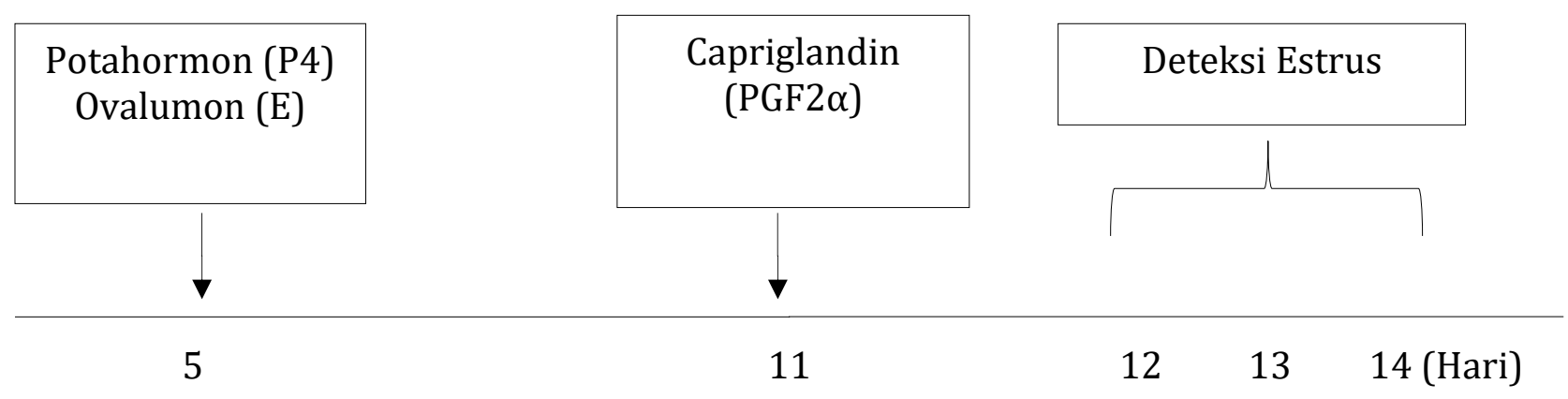

Gambar 4 Perlakuan 3

Perbedaan frekuensi dari Chi-Kuadrat sama atau lebih besar dari suatu harga yang ditetapkan pada taraf signifikan tertentu (dari tabel $\chi^{2}$ ). Rumus dasar dari uji chi kuadrat adalah:

$$
x^{2}=\sum \frac{(0-E)^{2}}{E}
$$

Keterangan: $\mathrm{O}=$ frekuensi hasil observasi; $\mathrm{E}=$ frekuensi yang diharapkan

\section{Peubah yang Diamati}

Berikut adalah beberapa peubah yang diamati ialah (1) respons estrus, (2) onset estrus, dan (3) durasi estrus.

1. Respons estrus adalah persentase sapi yang menunjukkan gejala estrus setelah penyuntikan hormon.

2. Onset estrus adalah jarak waktu mulai dari penyuntikan sampai munculnya gejala estrus.

3. Durasi estrus adalah jarak waktu mulai dari munculnya gejala estrus sampai hilangnya gejala estrus. 
Pengamatan respons estrus dilakukan 7 hari setelah penyuntikan hormon. Gejala estrus yang muncul adalah: vulva (merah, bengkak dan mengeluarkan lender estrus), menunjukkan tingkah laku menaiki sapi betina lain atau diam bila dinaiki sapi betina lain. Estrus diamati setiap 3 jam untuk satu hari sebelum dan sesudah waktu estrus, setelah memasuki estrus dilakukan 5 kali pengamatan setiap hari yaitu pada pukul: 06.00, 10.00, 14.00, 18.00 dan 22.00 WIB.

\section{HASIL DAN PEMBAHASAN}

\section{Respons Estrus Sapi FH Resipien}

Respon estrus sapi FH resipien setelah penyuntikan kombinasi hormon sinkronisasi estrus pada tiga perlakuan, semuanya memperlihatkan gejala estrus. Respon estrus sapi FH resipien secara keseluruhan mencapai 100\% (Tabel 1).

Tabel 1 Respons estrus setelah disinkronisasi dengan kombinasi hormon

\begin{tabular}{crrr}
\hline Perlakuan & $\begin{array}{c}\text { Jumlah } \\
\text { sapi } \\
\text { (ekor) }\end{array}$ & $\begin{array}{c}\text { Jumlah } \\
\text { sapi } \\
\text { yang } \\
\text { estrus } \\
\text { (ekor) }\end{array}$ & $\begin{array}{c}\text { Persentase } \\
\text { Respons } \\
\text { estrus } \\
\text { (\%) }\end{array}$ \\
\hline P1 & 5 & 5 & 100 \\
P2 & 5 & 5 & 100 \\
P3 & 5 & 5 & 100 \\
Jumlah & & & \\
(ekor) & 15 & 15 & \\
\hline
\end{tabular}

Keterangan: hasil uji Chi-Square menunjukkan tidak ada beda antara frekuensi hasil pengamatan dan harapan.

Hasil pengamatan terhadap respon estrus menunjukkan kombinasi hormone sinkronisasi estrus dari semua perlakuan efektif menggertak munculnya gejala estrus (Tabel 1). Pada P0 penyuntikan pertama hormon prostaglandin (Capriglandin) hari ke0 berperan dalam meregresikan Corpus Luteum (CL), sehingga kadar ormon progesteron dalam darah turun Rendahnya hormon progesterone akan memicu peningkatan hormon FSH di tingkat hipofisa yang akan merangsang pematangan folikel sampai pada tahap folikel de Graaf. Secara visual pada fase ini sapi betina akan meunjukkan gejala estrus yang akan diikuti dengan ovulasi. Pengulangan penyuntikan hormone prostaglandin (Capriglandin) pada hari ke-11 diharapkan semua sapi berada pada fase yang sama yaitu fase luteal. Setelah penyuntikan kedua (terakhir) diharapkan pemunculan estrus terjadi secara serentak.

Penyuntikan hormon GnRH (Fertagyl) pada hari ke 4 (P2) berperan merangsang hipofisa anterior untuk mensekresikan hormon-hormon gonad yaitu FSH dan LH. Hormon FSH dapat menstimulasi pertumbuhan folikel dan pematangan follikel ovarium, sedangkan FSH bersama LH menginduksi sekresi hormon estrogen pada folikel tersier atau de Graaf. Penyuntikan GnRH eksogen akan menyebabkan timbulnya gelombang folikuler pada $2-3$ hari kemudian. Penyuntikan hormon prostaglandin (Prostavet) pada hari ke-11 bertujuan untuk meregresikan CL sehingga muncul gejala estrus secara bersamaan.

Perlakuan tiga (P3), penyuntikan hormon progesteron (Potahormon) hari ke-5 akan meningkatkan kadar hormon progesteron dalam darah sehingga terjadi umpan balik negatif pada hipotalamus untuk melepaskan GnRH yang akhirnya terjadi pelepasan hormon FSH dan LH dari adenohipofisis dan akan terjadi pematangan folikel, pemunculan gejala estrus dan ovulasi. Penyuntikan hormon estrogen (Ovalumon) bersamaan pada hari ke-5 untuk sinkronisasi munculnya gelombang folikel. Penyuntikan hormon prostaglandin (Capriglandin) pada hari ke-11 bertujuan untuk meregresikan CL untuk menggertak munculnya estrus.

Tanda-tanda estrus yang muncul pada sapi FH resipien setelah perlakuan penyuntikan kombinasi hormon sinkronisasi estrus pada ketiga perlakuan rata-rata dengan ciri-ciri vulva yang membengkak, merah dan mengeluarkan lendir transparan (Gambar 6). Pengukuran dengan thermometer menunjukkan peningkatan suhu rektal 1 - 2 dari suhu tubuh. 


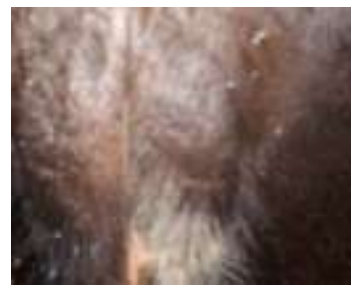

(a)

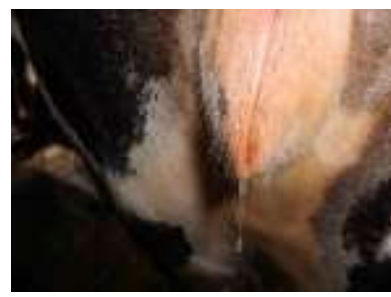

(b)
Gambar 5 Tanda estrus: (a) vulva bengkak (b) vulva berlendir

\section{Onset Estrus Sapi FH Resipien}

Onset estrus merupakan waktu timbulnya estrus dihitung mulai dari hari terakhir penyuntikan hormon (hari ke-11) sampai pertama kali munculnya gejala estrus. Pengamatan onset estrus dilakukan dengan melihat pemunculan gejala estrus melalui pengamatan visual tingkah laku sapi (menaiki sapi betina lain, diam bila dinaiki sapi betina lain) dan kondisi vulva (merah, bengkak, basah) dan keluar lendir transparan melalui vulva. Pengamatan onset estrus adalah pemunculan gejala estrus pada jam ke32, jam ke-48 dan jam ke-72 (Tabel 2).

Tabel 2 Onset estrus sapi FH resipien

\begin{tabular}{|c|c|c|c|c|c|c|}
\hline \multirow{3}{*}{ Perlakuan } & Jumlah. & \multicolumn{5}{|c|}{ Onset estrus jam ke- } \\
\hline & sapi & 32 & & 48 & & 72 \\
\hline & (ekor) & (ekor) & $(\%)$ & (ekor) & $(\%)$ & (ekor) (\% \\
\hline P1 & 5 & . & . & 1 & 20 & 48 \\
\hline P2 & 5 & - & - & 3 & 60 & 2 \\
\hline P3 & 5 & 1 & 20 & 1 & 20 & 3 \\
\hline Jumlah & 15 & 1 & & 5 & & 9 \\
\hline
\end{tabular}

Keterangan: Hasil uji Chi-Square menunjukkan tidak ada perbedaan.

Efektifitas perlakuan penyuntikan kombinasi hormon terhadap onset estrus bervariasi dari hari pertama sampai hari ke tiga setelah penyuntikan hormon sinkronisasi estrus. Hasil penelitian menunjukkan bahwa munculnya estrus pada perlakuan 3 yaitu penyuntikan kombinasi hormon progesteron dan estrogen pada hari ke-5 dan diikuti hormone prostaglandin pada hari k3-11 lebih awal dibandingkan perlakuan lain yaitu sebesar 20\%. Hal ini disebabkan karena penyuntikan hormon estrogen eksogen, menyebabkan lonjakan LH setelah 20 - 24 jam kemudian. Dampak secara visual adalah pemunculan tingkah laku estrus lebih cepat sehingga ovulasinya juga lebih cepat. Menurut Mcdougal et al. (1994) folikel dominan yang berada pada fase puncak pertumbuhan lebih besar peluangnya untuk berovulasi sesudah pemberian estrogen dibandingkan dengan yang berada pada fase pertumbuhan.

Menurut Moreira et al. (2000) sapi yang disuntik dengan PGF2 $\alpha$ akan menunjukkan gejala estrus dalam waktu 2 hari setelah penyuntikan. Normalnya sapi akan mengalami estrus dengan onset estrus $1-3$ hari setelah injeksi kedua PGF2 $\alpha$ dengan dosis 10 - 15 mg secara intramuskular (McDonald 1990). Semakin cepat tanda estrus muncul maka mengindikasikan semakin tepat pula metode tersebut untuk diaplikasikan karena akan mempermudah peternak untuk segera melakukan perkawinan pada ternaknya, sehingga lebih meningkatkan efesiensi waktu dalam manajemen peternakan khususnya untuk meningkatkan populasi ternak.

Hasil penelitian Handayani et al. (2015) pemberian prostaglandin 2 kali dengasn dosis $2 \mathrm{ml} /$ ekor menunjukkan estrus pada jam ke72 berkisar tertinggi $48,89 \%$. Ukuran sapi juga dapat mempengaruhi kecepata beredarnya hormon dalam darah untuk mencapai target organ. Sapi dengan bobot badan kecil akan menyebabkan hormon cepat mencapai sasaran, sedangkan pada sapi yang gemuk maka sebagian hormon akan larut dalam lemat. Goff (2004) mengemukakan bahwa senyawa prostaglandin bersifat asam, merupakan turunan dari asam lemak tidak jenuh (20 atom C) yang dihasilkan dari membaran fosfolipid oleh aktivitas Phospholipase A2, Cylooxygenase dan prostagtlandin shyntase spesifiik lainnya yang larut dalam lemak. Pengaruh paritas sangat juga tinggi pada onset estrus. Ismail (2009) mengemukakan bahwa onset estrus lebih terjadi pada ternak yang telah melahirkan lebih dari satu kali dibandingkan ternak yang pertama kali melahirkan atau kelahiran pertama. Ukuran ovarium juga berpengaruh pada onset estrus.

Sapi dara sering menunjukkan periode estrus yang lebih pendek dibandingkan dengan yang lebih tua. Jika dihubungkan 
dengan pertumbuhan dan perkembangan organ, maka sapi dara belum mengalami dewasa tubh sehingga oran reproduksinya belum berkembang sempurna yang mengakibatkan pada fungsi dan kemampuan reproduksinya belum maksimal. Hormon yang berkaitan dan bertanggungjawab terhadap pemunculan estrus adalah hormon estrogen meskipun tingginya level hormon estrogen akan menimbulkan estrus yang lebih lama meskipun tidak menjamin terjadinya ovulasi.

Sapi resipien dengan onset estrus tercepat adalah pemberian kombinasi hormone progesteron (Potahormon) dan estrogen (Ovalumon) pada penyuntikan hari kelima diikuti penyuntikan hormon prostaglandin pada hari ke-11, 1 ekor (20\%) menunjukkan estrus pada jam ke-32. Penelitian Bo et al. (2006) mendapatkan hasil bahwa pemberian/implant progesteron diiringi dengan pemberian estradiol benzoate akan mempercepat timbulnya estrus dan memperpendek interval antara waktu pemberian dan ovulasi. Hal ini secara teori dapat dipahami estrogen pada saat konsentrasi hormon progesteron dalam plasma rendah akan berpengaruh pada syaraf pusat yang akan tampak pada pemunculan gejala estrus. Pemberian homon progesterone dengan dosis $62,5 \mathrm{mg}$ menghasilkan onset estrus 7 ekor (70\%) pada hari ke $4-5$ atau pada jam ke $48-72$ (Pohan dan Thalib 2010). Hasil penelitian Siregar et al. (2014), penyuntikan hormone prostaglandin secara nyata memberikan onset estrus maksimal yaitu $100 \%$. Hal yang sama penggunaan kombinasi hormon prostaglandin dan progesteron (Malik et al. 2011).

\section{Durasi Estrus Sapi FH Resipien}

Durasi estrus atau lamanya estrus dihitung mulai dari pertama kali sapi menunjukkan gejala estrus setelah penyuntikan hormon sampai berakhirnya gejala estrus. Hasil pengamatan terhadap durasi estrus sapi $\mathrm{FH}$ resipien setelah diberi perlakuan dapat dilihat pada Tabel 3.
Tabel 3 Durasi estrus sapi FH resipien

\begin{tabular}{crrrrr}
\hline \multirow{2}{*}{ Perlakuan } & \multicolumn{4}{c}{ Durasi estrus jam ke } \\
\cline { 3 - 6 } & Jumlah (ekor) & \multicolumn{2}{c}{$<72$ jam } & \multicolumn{2}{c}{72 jam } \\
\cline { 3 - 6 } & & (ekor) & $(\%)$ & (ekor) & $(\%)$ \\
\hline P1 & 5 & 1 & 20 & 4 & 80 \\
P2 & 5 & 3 & 60 & 2 & 40 \\
P3 & 5 & 2 & 40 & 3 & 60 \\
Jumlah (ekor) & 15 & 6 & & 9 & \\
\hline
\end{tabular}

Keterangan: Hasil uji Chi-Square menunjukkan tidak ada perbedaan.

Durasi estrus selama 3 (72 jam) pada P1 lebih lama yaitu sebesar 80\% karena mekanisme dari fungsi hormon yang cukup panjang, yaitu melisiskan CL terlebih dahulu baru merangsang sekresinya hormon gonadotropin untuk proses folikulogenesis dan juga dikarenakan perkembangan CL dari masing-masing individu yang berbeda-beda (Hafez 2000).

Lamanya estrus juga bergantung pada jumlah dan kualitas folikel yang berbeda. Jumlah folikel yang banyak berkorelasi pula dengan estrogen yang dihasilkan juga semakin banyak sehingga dimungkinkan durasi estrus yang dihasilkan akan lama. Kontrol gelombang pertumbuhan folikel sangat penting dalam program superovulasi dan sinkronisasi estrus, yaitu mempengaruhi lama siklus estrus dan panjang fase luteal (Hafez 2000; Ramli et al. 2016).

Durasi estrus erat kaitanya dengan sifat farmakologis dan biokimia hormon PGF2 $\alpha$ yang mengaktifasi otot polos vagina. Murray (2009) mengemukakan bahwa hormon prostaglandin sangat efektif dalam mengaktifasi otot polos, disamping mempunyai efek inflamatori, vasodilatasi pembuluh darah, dan mengelusidasi cairan (Efendi et al. 2015). Menurut Stevenson (2010) PGF2 $\alpha$ dengan zat aktif dinoprost dapat menurunkan konsentrasi progesteron pada sapi dalam 72 jam. Secara umum hasil penelitian pada Tabel 3 menunjukkan bahwa timbulnya estrus paling banyak adalah pada hari ke 3 (72 jam) rata-rata yaitu sebesar $60 \%$ terdiri dari tiga perlakuan dengan penyuntikan kombinasi hormon sinkronisasi estrus sapi resipien. 


\section{Rekapitulasi Hasil Penelitian}

Hasil penelitian menunjukan secara umum onset estrus dan durasi estrus paling lama pada perlakuan P1 yaitu penyuntikan hormon prostaglandin (Capriglandin) 137,5 $\mathrm{mg} / 5 \mathrm{ml}$ pada hari ke-0 dan diulang kembali pada hari ke-11. Onset estrus tertinggi pada perlakuan 1, sejumlah 4 ekor sapi FH menunjukkan gegala estrus pada jam ke-72. Hany satu ekor sapi resipien yang menunjukkan gejala estrus pada jam ke-48 (hari ke2).

Tabel 4 Rekapitulasi hasil analisis tiga perlakuan hormon sinkronisasi estrus

\begin{tabular}{|c|c|c|c|c|c|c|c|c|c|c|c|c|}
\hline \multirow{4}{*}{ Perlakuan } & \multirow{4}{*}{$\begin{array}{l}\text { Jumlah } \\
\text { (ekor) }\end{array}$} & \multirow{4}{*}{$\begin{array}{c}\text { Respon } \\
\text { estrus } \\
(\%)\end{array}$} & \multicolumn{10}{|c|}{ Kualitas Estrus } \\
\hline & & & \multicolumn{6}{|c|}{$\begin{array}{l}\text { Onset estrus jam ke } \\
\text { (ekor) }\end{array}$} & \multicolumn{4}{|c|}{ Durasi estrus jam ke } \\
\hline & & & \multicolumn{2}{|c|}{32} & \multicolumn{2}{|c|}{48} & \multicolumn{2}{|c|}{72} & \multicolumn{2}{|c|}{$<72$} & \multicolumn{2}{|c|}{72} \\
\hline & & & (ekor) & $(\%)$ & (ekor) & $(\%)$ & (ekor) & $(\%)$ & (ekor) & $(\%)$ & (ekor) & $(\%)$ \\
\hline P1 & 5 & 100 & - & - & 1 & 20 & 4 & 80 & 1 & 20 & 4 & 80 \\
\hline P2 & 5 & 100 & - & - & 3 & 60 & 2 & 40 & 3 & 60 & 2 & 40 \\
\hline P3 & 5 & 100 & 1 & 20 & 1 & 20 & 3 & 60 & 2 & 40 & 3 & 60 \\
\hline
\end{tabular}

Keterangan: Hasil analisis Chi Square menunjukan tidak berbeda nyata $(\mathrm{P}>0,05)$ pada semua perlakuan.

Hasil pengujian uji Chi-Square untuk P1 yang munculnya estrus pada hari ke 2 (48 jam) $20 \%$ tidak berbeda nyata $(P>0,05)$ dibandingkan dengan perlakuan 2 (P2) 60\% karena pada perlakuan 1 dan 2 ada pengulangan penyuntikan PGF2 $\alpha$ yang masing-masing sifat farmakologis dan biokimia PGF2 $\alpha$ berbeda walaupun pada hari ke 11 semua sapi berada dalam fase luteal yaitu fase saat korpus luteum berfungsi dan berada pada fase yang sama sehingga 2 hari (48 jam) setelah penyuntikan estrus bisa serentak. Menurut Moreira et al. (2000) sapi yang diinjeksi dengan PGF2 $\alpha$ akan estrus dalam waktu 2 hari setelah penyuntikan.

Hasil analisis chi-Square untuk P1 munculnya estrus pada hari ke 2 (48 jam) $20 \%$ tidak berbeda nyata $(\mathrm{P}>0,05)$ dibandingkan dengan P3 munculnya estrus pada hari ke 1 (32 jam) 20\% karena pada P1 dan P2 dilakukan pengulangan penyuntikan PGF2 $\alpha$ yang masing-masing sifat farmakologis dan biokimia hormone PGF2 $\alpha$ berbeda, tetapi pada perlakuan 3 (P3) pada hari ke 5 penyuntikan kombinasi kecenderungan hormon progesteron dan estrogen untuk mensinkronkan munculnya gelombang folikel selain itu hormon estrogen terjadi umpan balik positif yang berpengaruh pada tingkah laku estrus dan pengamatan visual vulva (bengkak, merah dan basah) lebih nyata.
Hasil analisis Chi-Square untuk P2 menunjukkan pemunculan estrus pada hari ke-2 (48 jam) yaitu $60 \%$ tidak berbeda nyata $(\mathrm{P}>0,05)$ dibandingkan dengan $\mathrm{P} 3$ munculnya estrus pada hari ke 1 (32 jam) 20\%. Meskipun penyuntikan hormon pada perlakuan P2 dan P3 penyuntikan hormonnya berbeda yaitu GnRH (P2) dan progesterone dan estrogen (P3), keduanya merangsang pelepasan hormon FSH dan LH sehingga terjadi pematangan folikel, estrus dan ovulasi. Pada P3 penyuntikan hormon estrogen pada hari ke-5 secara memberikan ciri estrus yang lebih jelas (vulva bengkak, merah dan basah lebih nampak. Secara umum persentase onset estrus sapi resipies $\mathrm{FH}$ yang disuntik kombinasi hormon onset berada pada hari ke-3 (72 jam) dan durasi estrus paling banyak berlangsung selama 3 hari (72 jam).

\section{KESIMPULAN DAN IMPLIKASI}

Berdasarkan hasil penelitian yang telah dilakukan dapat diambil kesimpulan bahwa penyuntikan kombinasi hormon sinkronisasi estrus sapi FH resipien dengan menggunakan hormon GnRH, estrogen, progesteron dan prostaglandin sama baiknya dalam memberikan respon estrus, onset estrus dan durasi estrus. Disarankan menggunakan kombinasi hormon progesterone (Potahormon) dan estrogen (Ovalumon) 
pada hari ke-5 dan hormon prostaglandin (Capriglandin) pada hari ke-11, agar lebih efisien dari segi ekonomi.

\section{DAFTAR PUSTAKA}

Bo GA, PS Baruseloli, PM Chesta, and CM Martin. 2006. The Timing of Ovulation and insemination schedules in superstimulated catlle. Theriogenology. 65(1): 89 - 101.

Cerri RLA, JEP Santos, SO Juchem, KN Galvao, and RC Chebel. 2004. Timed artificial insemination with estradiol cypionate or insemination at estrus in high-producing dairy cows. J.Dairy Sci. 87: 3704-3715.

Chenault JR, DD Kratser, RA Rzepkowski, and MC Goodwin. 1990. LH and FSH response of Holstein Heifer to Fertirelin Acetate, Gonadrelin and Buserin. Theriogenology 53:1407-1414.

Colazo MG and MF Martínez. 2005. Effect of estradiol valerate on ovarian follicle dynamics and superovulatory response in progestin-treated cattle. Theriogenology; 63:1454-1468.

Efendi M, Tn Siregar, Hamdan, Dasrul, Cn Thasmi, Razali, A Sayuti, dan B Panjaitan. 2015. Angka kebuntingan sapi lokal setelah diinduksi dengan protokol ovsynch. Jurnal Medika Veteriner. Vol. 9 (2): 159 -162.

Elsden RP dan Seidel GE JR. 1992. Embryo transfer procedure for cattle.In Animal Reproduction Laboratory.Colorado State University. Fort Collins, Colorado.

Frandson RD. 1996. Anatomi dan Fisiologi Ternak. Edisi ke-7, diterjemahkan oleh Srigandono B dan Praseno K, Gadjah Mada University Press, Yogyakarta.

Goff AK. 2004. Steroid Hormon Modulation of Prostaglandin Secretionin the Ruminant Endometrium During the Estrous Cycle. J. Of Biology Reproduction 71: 11-16.

Hafez B. 2000. Reproduction In Farm Animal.

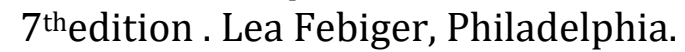

Handayani UF, M Hartono, dan Siswanto. 2015. Respon kecepatan timbulnya estrus dan lama estrus pada berbagai paritas sapi bali setelah dua kali pemberian prostaglandin F2 $\alpha$ (PGF2 $\alpha$ ). Jurnal
Hartantyo S. 1995. Calculation of percent progesterone in skim milk fraction when centrifugation temperature and butter fat of whole milk are known. Bull. FKH-UGM.Vol. XIV No. 2:1-6.

Ismail M. 2009. Onset dan Intensitas estrus Kambing pada umur yang berbeda. J. Agroland. 16 (2): 180 - 186.

Jillella D. 1992. Embryo transfer technology and its aplication in developing countries. A Monograph Development for National Seminar to be conducted in India, Indonesia, Malaysia, Philippines, Srilangka and Thailand. Oktober 1992.

King KG, Jr GE Seidel, dan RP Elsden. 1995. Bovine embryo transfer pregnancies: abortion rates and caracteristics of calves. J. Anim. Sci. 61:747-757.

Larson JE, GC Lamb, JS Stevenso, SK Johnson, TW Geary, DJ Kesler, JM Dejarnette, FN Schrick, A DiCoztanzo, and JD Arseneau. 2006. Synchronization of Estrus in Sucled Beef Cows for Detected Estrous and Artificial Insemination Using GonadotropingReleasing Hormone, Prostaglandin F2 $\alpha$, and Progesteron. J. Anim. Sci. 71:61.

Malik A, H Wahid, Y Rosnina, M Bukar, A Kasim, and $\mathrm{M}$ Sabri. 2011. Effect of resynchronization with progesterone and prostaglandin F2 alpha on estrus response and pregnancy rate in beef catlle. J. Anim. Vet. Adv. 10: 2474 - 2478.

Marawali A. 2001. Dasar-Dasar ilmu reproduksi ternak. Departemen Pendidikan Nasional Direktorat Pendidikan Tinggi Badan Kerja Sama Perguruan Tinggi Negeri Indonesia Timur, Jakarta.

Mcdougall and NB Willamson. 1995. Follicle pattern during extended periods of post partum ovulation in pasture-fed dairy cows. Research Veterinary Science 58: 212.

Moreira dan WW Thatcher. 2000. Effect of Day of the estrous Cycle at the Inisiation of a Timed Artificial Insemination Protocol on Reproductive Responses in Dairy Heifers. Journal Anim. Sci. 78:1568-157.

Pohan A dan C Talib. 2010. Aplikasi hormon progesteron dan estrogen pada betina induk sapi bali an-estrus post-partum yang digembalakan di Timor Barat, Nusa Tenggara 
Timur. Pross. Seminar Nasional Teknologi Peternakan dan Veteriner. 19 - 24.

Putro PP. 2008. Dampak crossbreeding terhadap reproduksi induk turunannya: Hasil Studi Klinis. Lokakarya Lustrum VIII Fak. Peternakan UGM, 8 Agustus 2009.

Putro PP dan A Kusumawati. 2014. Dinamika folikel ovulasi setelah sinkronisasi estrus dengan prostaglandin F2a $\alpha$ pada sapi perah. Jurnal Sain Veteriner 32 (1): 22 - 31.

Ramli M, TN Siregar, CN Thasmi, Dasrul, S Wahyuni, dan A Sayuti. 2016. Hubungan antara intensitas estrus dengan konsentrasi estradiol pada sapi aceh saat inseminasi. Jurnal Medika Veterinaria, Vol. 10 (1): $27-30$.

Schmitt EJP, M Drost, T Diaz, C Roomes, and WW Tacher. 1996. Effect of a gonadotropinreleasing hormone agonist on follicle recruitment and pregnancy rate in cattle.J. Anim Sci. 74:154-161.

Siregar TN, H Hamdan, G Riady, B Panjaitan, D Aliza, EF Pratiwi, T Darianto, dan Husnurrizal.
2014. Efficacy of two estrus synchronization methods in Indonesian Aceh CatlleInter. J. Vet. Sci. 4(2): $87-91$.

Solihati N. 2005. Pengaruh metode pemberian PGF2 $\alpha$ dalam sinkronisasi estrus terhadap angka kebuntingan sapi perah anestrus. Fakultas Peternakan. Universitas Padjajaran, Bandung.

Stevenson JS and AP Phatak. 2010. Rates of luteolysis and pregnancy in dairy cowsafter treatment with cloprostenol or dinoprost.Theriogenology 73:1127-1138.

Tenhagen BA. 2005. Factors influencing conception rate after synchronization of ovulation and timed artificial inseminationA review. Dtsch. Tieraerztl. Wochenschr. 112:136-141.

Wodzicka TM, IK Sutama, IG Putu, dan TD Chaniago. 1991. Reproduksi tingkah laku dan produksi ternak Indonesia. Gramedia Pustaka Utama, Jakarta. 